\title{
MAHASISWA FKM UNDANA SEBAGAI AGENT OF CHANGE PENCEGAHAN PENYEBARAN COVID-19
}

\author{
Serlie K. A. Littik1), S. P. Manongga'), Ramses V Elim³) \\ 1,2)Fakultas Kesehatan Masyarakat Undana, \\ 3)Politeknik Pertanian Negeri Kupang \\ 1)serlie.littik@staf.undana.ac.id, 2)boymanongga1959@gmail.com, \\ 3)007234victor@gmail.com
}

\section{Histori artikel}

Received:

18 April 2021

Accepted:

30 April 2021

Published:

30 April 2021

\begin{abstract}
Abstrak
Severe Acute Respiratory Syndrome-Related coronavirus 2 (SARS-CoV-2) adalah virus yang menyerang sistem pernapasan (Covid-19). Merespon kondisi Covid-19 yang terjadi di seluruh dunia, Badan Kesehatan Dunia megeluarkan pedoman transisi menuju adaptasi kebiasaan baru, yaitu mencuci tangan, menjaga jarak, menggunakan masker, menghindari tempat kerumunan, menjaga kebersihan diri, serta tetap tinggal di rumah. Kegiatan pengabdian ini bertujuan untuk meningkatkan pemahaman mahasiswa FKM Undana tentang Covid-19 dan penyebarannya, serta penerapan adaptasi kebiasaan baru mahasiswa di tengah masyarakat. Melalui penyuluhan, diskusi, dan pemberian paket bantuan bahan makanan serta alat kesehatan, 30 orang mahasiswa Fakultas Kesehatan Masyarakat Undana berkomitmen untuk menjadi agen perubahan untuk menerapkan kebiasaan baru di tengah masyarakat.
\end{abstract}

Kata Kunci: pengabdian mahasiswa, Pencegahan COVID-19 
Abstract. Severe Acute Respiratory Syndrome-related coronavirus 2 (SARS-CoV-2) is a virus that attacks the respiratory system (Covid-19). Responding to the conditions of Covid-19 that have occurred around the world, the World Health Organization issued transition guidelines towards adapting to new habits, namely washing hands, maintaining distance, using masks, avoiding crowded places, maintaining personal hygiene, and staying at home. This activity aims to increase students' understanding of Covid-19 and its spread, as well as the application of adaptation to new student habits in society. Through counseling, discussions, and provision of food and medical equipment assistance packages, 30 Undana Faculty of Public Health students are committed to becoming agents of change to implement new habits in the community.

Keywords: students service activity, prevention of COVID-19

\section{PENDAHULUAN}

Virus Corona atau Severe Acute Respiratory Syndromecoronavirus 2 (SARS-CoV2) adalah virus yang menyerang sistem pernapasan. Penyakit karena infeksi virus ini disebut Corona Virus Disease 2019 atau yang dikenal dengan Covid-19. Penyakit ini menyebar melalui tetesan air liur (droplets) atau muntah (fomites), kontak dekat dengan orang yang terinfeksi tanpa pelindung dan adanya kontak dengan benda yang sering tersentuh (virus ini dapat bertahan selama 3 hari pada permukaan benda). Masa inkubasi Covid-19 rata-rata 5-6 hari, dengan jarak 1 hingga14 hari namun dapat mencapai lebih dari 14 hari. Orang yang terinfeksi dapat langsung dapat menularkan sampai dengan 48 jam (Kementerian Kesehatan $\mathrm{RI}, 2020)$.

Kasus Covid-19 di Indonesia diketahui pertama kali pada tanggal 2 Maret 2020 dengan jumlah terkonfirmasi positif sebanyak 2 kasus. Penyebaran Covid-19 yang meningkat setiap harinya menyebabkan Covid-19 ditetapkan Presiden Joko Widodo menjadi Bencana Nasional dengan Keputusan Presiden Nomor 12 tahun 2020 tentang Penetapan Bencana Nasional Penyebaran Corona Virus Disease 2019 (Covid-19), setelah sebelumya menetapkan Keputusan Presiden Nomor 11 tahun 2020 tentang Penetapan Kedaruratan Kesehatan Masyarakat (KKM) Covid-19.

Provinsi Nusa Tenggara Timur (NTT) pertama kali terkonfirmasi positif Covid-19 pada tanggal 9 April 2020 sebanyak 1 (satu) kasus. Menurut Gugus Tugas Percepatan Penanganan Covid-19 Provinsi NTT hingga tanggal 11 Agustus 2020, jumlah kasus positif sebanyak 157 Kasus, dimana 132 kasus sembuh, dan 1 orang meninggal. Sebagian besar kasus berasal dari pelaku perjalanan.

Merespon situasi yang terjadi sebagai akibat dari pandemi Covid-19 yang telah mengancam berbagai sektor kehidupan, Badan Kesehatan Dunia mengeluarkan pedoman transisi menuju adaptasi kebiasaan baru di tengah pandemi Covid-19. Cara terbaik yang dianjurkan untuk mencegah dan memperlambat penyebaran virus Covid-19 yaitu melindungi diri dan orang-orang di sekitar dari penularan dengan sering mencuci tangan dengan air atau menggunakan cairan yang mengandung alkohol, menjaga jarak minimal 1 meter dari orang 
lain, menghindari pergi ke tempat kerumunan, menghindari menyentuh mata, hidung dan mulut, memastikan diri dan orang di sekitar mampu menjaga kebersihan udara di lingkungan, serta tetap tinggal di rumah (Putri, 2020). Namun anjuran ini belum dilaksanakan oleh semua orang.

Penerapan adaptasi kebiasaan baru bukan hal mudah. Pengakuan beberapa orang menunjukkan mereka tidak percaya Covid-19 akan menjangkiti mereka (Khoirur Rozi, n.d.). Masih banyak ditemukan orang yang tidak menggunakan masker karena menurut mereka pada saat menggunakan masker mereka merasa sesak nafas, tidak terbiasa dan merepotkan. Mencuci tangan dengan hand sanitizer ataupun mencuci tangan pada tempat yang sudah disediakan juga jarang dilakukan, tidak tersedianya air bersih dan sabun pada tempat cuci tangan di area publik, belum lagi tentang menjaga jarak saat berinterkasi dengan orang lain yang seringkali di abaikan karena pengaruh kehidupan sosial budaya yang relatif kompleks. Hal-hal ini akan mempersulit penerapan adaptasi kebiasaan baru (protocol kesehatan) di tengah masyarakat.

Sebagai tumpuan harapan bangsa Indonesia, mahasiswa diharapkan membawa perubahan bagi negara Indonesia untuk bisa bersaing dengan negara-negara di dunia. Mereka harus memberikan kontribusi yang riil untuk perubahan yang lebih baik (agent of social control). Dalam masa pandemi Covid-19, tiga puluh Mahasiswa Fakultas Kesehatan Masyarakat (FKM) melalui kegiatan sosialisasi tentang covid-19 dan penerapan protocol kesehatan secara daring dipersiapkan untuk menjadi agent of change sehingga mereka perlu dibekali informasi tentang dampak Covid-19 terhadap berbagai aspek kehidupan, mengenal, menerapkan dan berkomitment untuk menjalankan protocol kesehatan dalam kehidupan mereka sehingga mereka dapat melakukan tindakan pencegahan penularan Covid-19 tersebut terhadap diri sendiri, keluarga, dan lingkungan masyarakat.

Beberapa permasalahan sasaran yang berhasil di identifikasi adalah:

1. Belum disiplinnya mahasiswa menerapkan protocol kesehatan.

Banyak mahasiswa belum sadar bahaya Covid-19. Banyak diantara mereka yang menganggap bahwa virus ini tidak berada di sekitar mereka. Ada juga yang beranggapan mereka masih muda, dengan kekebalan tubuh yang masih baik, mereka tidak akan terinfeksi Covid-19. Selain itu ada juga yang tidak menerapkan protocol kesehatan karena lingkungan sekitar mereka berperilaku yang sama, dan tidak ada sanksi di dalamnya. Jika hal ini berlangsung terus, maka mahasiswa juga dapat menjadi penyebar virus corona bahkan terinfeksi virus ini karena tidak disiplin menerapkan protocol kesehatan.

2. Dampak ekonomi akibat Covid-19.

Banyak mahasiswa FKM yang berasal dari Kabupaten di wilayah Provinsi NTT memiliki orang tua yang bekerja sebagai petani atau sektor swasta lainnya. Saat pandemic Covid19, mereka mengalami kesulitan ekonomi karena pekerjaannya terdampak. Dengan 
pendapatan orang tua yang berkurang, berkurang juga kiriman uang untuk anak mereka. Dampaknya adalah mahasiswa FKM harus pandai mengatur keuangan mereka, dengan berbagai cara, diantaranya adalah mengurangi konsumsi pangan. Hal ini beresiko menurunkan kekebalan tubuh mahasiswa mereka. Untuk itu mereka memerlukan bantuan.

3. Kekurangan alat dan bahan kesehatan

Dengan dampak ekonomi yang dirasakan mahasiswa, mereka terkendala dengan kurangnya alat atau bahan kesehatan seperti masker dan hand sanitizer yang harus dibeli untuk digunakan ketika terpaksa berinteraksi di luar rumah.

\section{METODE}

Metode pendekatan yang ditawarkan untuk menyelesaikan prioritas masalah yang telah disepakati bersama.

a) Penyuluhan dan diskusi dengan 30 mahasiwa FKM secara daring

b) Pemberian langsung paket bahan makanan dan alat/bahan kesehatan bagi mahasiswa FKM yang menjadi sasaran di tempat tinggal (kos kosan) mahasiswa

c) Pemantauan dan Evaluasi

Prosedur kerja untuk mendukung realisasi metode yang ditawarkan. Setelah tercapai kesepakatan metode di atas, maka prosedur kerja yang dilakukan adalah:

a) Persiapan berbagai hal yang berhubungan dengan metode, meliputi

1. Pembuatan materi penyuluhan dan diskusi tentang bahaya/dampak Covid-19 dan penerapan protocol kesehatan dalam kehidupan sehari-hari oleh ketua tim

2. Pengadaan paket zoom untuk 30 mahasiswa FKM oleh ketua tim

3. Pengadaan paket pemberian bahan makanan oleh tim pada hari Jumat, 25 September 2020, jam 12.00-14.00 WITA

4. Pengadaan paket alat/bahan kesehatan (masker, sabun, dan hand sanitizer) oleh tim pada hari Jumat, 25 September 2020, 12.00-14.00 WITA

5. Pemberian informasi pelaksanaan kegiatan penyuluhan, diskusi dan pemberian paket bahan makan dan alat/bahan kesehatan kepada mahasiswa sasaran oleh ketua tim pada hari Jumat, 25 September 2020, jam 09.00 WIT

b) Pelaksanaan Kegiatan

1. Penyuluhan dan diskusi tentang bahaya/dampak Covid-19 dan penerapan protocol kesehatan dalam kehidupan sehari-hari dengan 30 mahasiswa FKM yang dilaksanakan via aplikasi zoom pada hari Sabtu, 26 September 2020, Jam 10.0012.00 WITA

2. Pemberian langsung paket bahan makanan dan alat/bahan kesehatan kepada mahasiswa FKM yang menjadi sasaran di tempat tinggal (kos kosan) mahasiswa pada hari Minggu, 27 September 2020, jam 11.00-13.00 WITA 
c) Evaluasi

Dilaksanakan untuk mendapatkan penilaian dari sasaran terkait kegiatan ini guna perbaikan kegiatan di masa yang akan datang. Evaluasi dilaksanakan secara daring lewat google form hari Minggu, 27 September 2020, jam 15.00 WITA Selain itu juga ada evaluasi internal tim.

d) Pembuatan laporan

Rencana kegiatan yang menunjukkan langkah-langkah solusi

a) Penyuluhan dan diskusi tentang bahaya/dampak Covid-19 dan penerapan protocol kesehatan dalam kehidupan sehari-hari

b) Pembagian paket bahan makanan dan paket alat/bahan kesehatan

c) Evaluasi tim

\section{HASIL DAN PEMBAHASAN}

\section{Pelaksanaan Kegiatan}

Kegiatan pengabdian pada masyarakat ini dilaksanakan dalam dua tahap, yaitu penyuluhan dan diskusi untuk meningkatkan pemahaman mahasiswa FKM Undana dan pembagian paket bantuan.

\subsection{Penyuluhan dan Diskusi tentang Covid-19}

Kegiatan penyuluhan dan diskusi ini diadakan secara online pada hari Sabtu, 26 September 2020 dengan diikuti oleh 30 orang peserta yang merupakan mahasiswa dan 2 dosen FKM Undana, dengan Narasumber Dr. Serlie Littik.
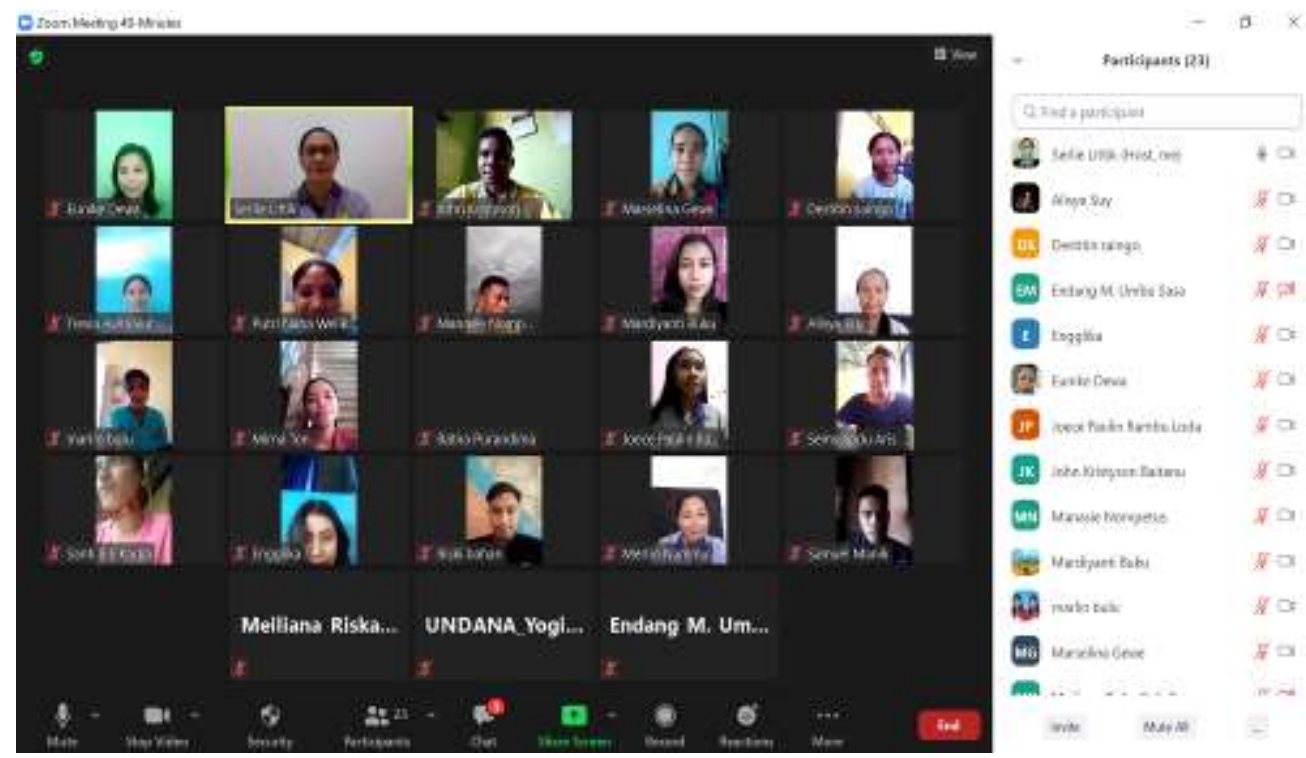

Gambar 1. Peserta Kegiatan Penyuluhan dan Diskusi Covid 19

Sebagian besar peserta kegiatan ini adalah perempuan. Hal ini wajar karena komposisi mahasiswa perempuan di FKM Undana jauh lebih banyak dari laki-laki. Sebagian besar diantaranya berada pada semester 5 dan 7 karena mereka sedang melaksanakan praktek lapangan. 
Setelah penyuluhan terkait Covid-19, terutama peningkatan kasus yang semakin tinggi di Kota Kupang, maka dilaksanakan diskusi terkait alasan tidak disiplinnya masyarakat, khususnya mahasiswa dalam penerapan kebiasaan baru ini. Hasil diskusi ini adalah sebagai berikut:

a) Persepsi kemungkinan terinfeksi virus corona

Cukup banyak mahasiswa (32\%) yang awalnya masih memiliki persepsi bahwa mereka tidak mungkin terifeksi virus corona. Setelah dipaparkan bukti (data) peningkatan kasus, dan mengapa hal tersebut terjadi, maka terjadi perubahan pemahaman. Mereka akhirnya paham bahwa Covid-19 dapat menginfeksi siapa saja yang tidak disiplin menerapkan protocol kesehatan.

b) Banyak mahasiswa tidak disiplin menerapkan protocol kesehatan.

Alasan mahasiswa tidak menerapkan protocol kesehatan adalah:

1. Tidak melihat langsung bahaya Covid. Meskipun terjadi peningkatan kasus di Kota Kupang, namun peserta penyuluhan tidak menaruh perhatian yang cukup karena jarang melihat penyakit ini menginfeksi keluarga/orang dekat mereka. Mereka tidak memiliki pengalaman (ada saudara/orang dekat yang mengalami hal ini - tidak seperti penyakit lain misalnya DBD, malaria) terkait Covid-19.

2. Lingkungan (pergaulan) sekitar tidak menerapkan protokol kesehatan. Peserta penyuluhan terkadang merasa risih harus terus menggunakan masker ketika berada di tengah teman-temannya atau lingkungan yang tidak menggunakan masker. Diperlukan motivasi terus menerus kepada mereka untuk disiplin menerapkan kebiasaan baru ini. Mahasiswa FKM harus menjadi contoh adaptasi kebiasaan baru untuk mencegah penyebaran corona virus.

Setelah mengidentifikasi alasan mahasiswa untuk tidak disiplin menerapkan kebiasaan baru, maka tim bersama mahasiswa mengidentifikasi alternative solusi agar mereka mau menerapkan protokol kesehatan ini. Beberapa alternatif solusi tersebut adalah:

1. Sosialisasi tiada henti dan tidak pernah bosan

Sebagian besar mahasiswa menyarankan agar terus dilakukan sosialisasi terkait Covid-19 ini. Sosialisasi terus menerus diperlukan agar masyarakat umum, khususnya mahasiswa tidak lupa untuk menerapkan kebiasaan baru ini. Juga diperlukan pemberian informasi terkait peningkatan kasus Covid-19 di Kota Kupang agar mereka sadar bahwa virus ini nyata dan dapat menginfeksi semua orang yang tidak menerapkan protocol kesehatan.

Sosialisasi ini dapat dilakukan secara langsung maupun tidak langsung oleh pemerintah, pihak kampus, dan bahkan oleh mereka sendiri.

2. Edukasi kepada tokoh masyarakat, tokoh agama, dan tokoh public 
Sebagian besar mahasiswa $(82,2 \%)$ menyarankan agar Edukasi kepada tokoh masyarakat, tokoh agama, dan tokoh publik. Hal ini dimaksudkan agar masyarakat melihat contoh dari tokoh-tokoh tesebut agar mereka termotivasi untuk menerapkan kebiasaan baru ini.

3. Pemerintah mengeluarkan peraturan penegakan hukum displin pencegahan penyebaran Covid-19 (memberikan sanksi bagi pelanggar)

Sebagian besar (96.5\%) mahasiswa peserta diskusi setuju agar pemerintah daerah mengeluarkan peraturan penegakan hukum displin pencegahan penyebaran Covid19, yaitu dengan memberikan sanksi bagi pelanggar.Ternyata banyak mahasiswa yang belum mengetahui adanya sanksi tersebut. Padahal pemerintah daerah Provinsi NTT lewat gubernur telah mengeluarkan aturan ini lewat Peraturan Gubernur NTT Nomor 49 tahun 2020.

Sanksi yang diberikan juga adalah :

a. Perorangan :

1) Teguran Lisan

2) Teguran Tertulis

3) Denda paling sedikit Rp. 50.000,- paling banyak Rp. 250.000,-

b. Pelaku Usaha :

1) Teguran Lisan

2) Teguran Tertulis

3) Denda paling sedikit Rp. 100.000,- paling banyak Rp. 5.000.000,-

4) Penghentian sementara operasional usaha

5) Pencabutan izin usaha

Diperlukan sosialisasi terkait aturan gubernur ini dan pengawasan dari semua pihak untuk penerapan aturan ini.

Mahasiswa peserta penyuluhan dan diskusi setuju untuk meningkatkan kesadaran bahwa untuk bergerak di bidang preventif sehingga menjadi teladan dan memberi pengaruh positif yang sangat diperlukan lingkungan sekitar, apalagi di masa pandemi covid ini. Mereka berkomitmen untuk selalu menerapkan protokol kesehatan dan menghindari perkumpulan dan pergaulan di luar rumah dengan teman-teman yang memiliki perilaku hidup yang tidak sehat agar dapat mencegah penularan Covid-19. Mereka juga mendaftarkan beberapa hal yang akan dilakukan, yaitu:

a. Disiplin menerapkan protokol kesehatan (menjadi teladan bagi lingkungan sekitar)

b. Mengajak dan / mengingatkan teman/orang sekitar untuk menerapkan protokol kesehatan

c. Turut membantu sosialisasi tentang Covid 19 
1.2 Pembagian paket bantuan bahan makanan dan alat/bahan kesehatan

Setelah mahasiswa ditingkatkan pemahamannya, dilakukan pembagian paket bantuan bagi 30 orang mahasiswa sasaran yang telah terdata terkena dampak Covid-19.
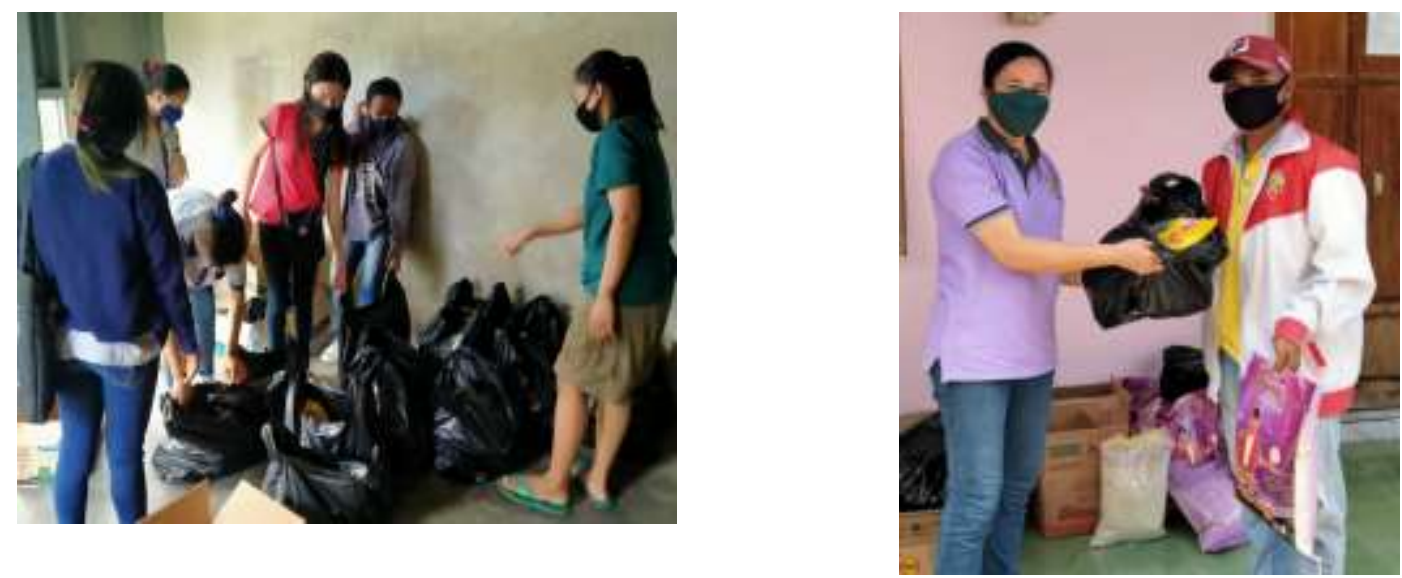

Gambar 2. Distribusi paket bantuan bagi 30 orang mahasiswa

Bantuan bagi mahasiswa berupa beras $5 \mathrm{~kg}$, minyak goreng 2 liter, susu 10 sachet, gula 1 kilogram, daun the 1 kotak, sabun mandi 6 batang, masker 10 buah, dan hand sanitizer 1 botol (100 ml). Paket bantuan diserahkan langsung kepada mahasiswa sasaran dengan bantuan 3 orang mahasiswa.

\section{Evaluasi Kegiatan}

Evaluasi yang dilaksanakan menunjukkan bahwa sebagian besar mahasiswa menilai kegiatan ini sangat bermanfaat $(92,8 \%)$.

Mereka berharap agar kegiatan seperti ini diadakan lagi, terutama diskusi melibatkan mahasiswa untuk meningkatkan tekat mereka agar bisa berkomitmen menjadi teladan dalam menerapkan kebiasaan baru di maa pandemic Covid-19 ini.

"Sangat baik karena dengan adanya kegiatan ini rasa peduli kita terhadap sesama semakin tinggi dan bisa membuat mahasiswa serta masyarakat lainnya bisa menerapkan protokol kesehatan dgn baik. Semoga Teman" yg ikut serta dalam kegiatan ini bisa menerapkan prinsip serta protokol kesehatan dilingkungan sekitar dengan baik karena Mencegah lebih baik daripada mengobati."

"Terima kasih telah membuat kegiatan ini melalui kegiatan ini sudah sangat membantu para mahasiswa semoga kita semua selalu sehat dan masalah pandemi corona cepat selesai untuk sarannya semoga kedepannya pembagian bantuan ini bukan hanya pada saat adanya pandemi corona saja".

Selain itu agar kegiatan dilaksanakan dengan sasaran yang lebih luas, melibatkan lebih banyak mahasiswa. 


\section{KESIMPULAN}

Kegiatan pengabdian kepada mahasiswa ini berlangsung dengan baik. Penyuluhan dan diskusi yang dilaksanakan berhasil meningkatkan pemahaman peserta sehingga ada komitmen untuk disiplin menerapkan kebiasaan baru untuk mencegah penyebaran virus corona. Paket bantuan baik bahan makanan maupun alat/bahan kesehatan berhasil didistribusikan bagi semua mahasiswa sasaran dengan baik.

\section{DAFTAR PUSTAKA}

Kementerian Kesehatan RI. (2020). Pedoman Kesiapsiagaan Menghadapi Infeksi Novel Coronavirus (2019-nCoV). Kementerian Resehatan RI. https://www.kemkes.go.id/resources/download/infoterkini/Coronavirus/DOKUMEN_RESMI_Pedoman_Kesiapsiagaan_nCoV_Indonesia_ 28 Jan 2020.pdf

Khoirur Rozi. (n.d.). Tiga Alasan Utama Seseorang Tidak Patuhi Protokol Kesehatan. https://www.ayojakarta.com/read/2020/09/28/25113/tiga-alasan-utama-seseorangtidak-patuhi-protokol-kesehatan

Putri, G. S. (2020). WHO: Pandemi Covid-19 Meningkat Pesat, Ini yang Harus Dilakukan. https://www.kompas.com/sains/read/2020/03/25/180000223/who--pandemi-covid-19meningkat-pesat-ini-yang-harus-dilakukan.

Kementerian Kesehatan RI (2020). Pedoman Kesiapsiagaan Menghadapi Infeksi Novel Coronavirus (2019-nCoV). Kementerian Kesehatan RI Direktorat Jenderal $\begin{array}{llll}\text { Pencegahan dan Pengendalian } & \text { Penyakit }\end{array}$ https://www.kemkes.go.id/resources/download/infoterkini/Coronavirus/DOKUMEN_RESMI_Pedoman_Kesiapsiagaan_nCoV_Indonesia_ 28\%20Jan\%202020.pdf

WHO (2020).Penyakit Infeksi emerging akibat virus termasuk COVID 19 Metode metode deteksi, pencegahan, respons dan pengendalian. https://openwho.org/courses/pengantar-COVID-19. 